\title{
Article \\ pH Measurement of Cement-Based Materials: The Effect of Particle Size
}

\author{
Poh Yee Loh ${ }^{1}$ D , Payam Shafigh ${ }^{1, * \mathbb{D}}$, Herda Yati Binti Katman ${ }^{2, *}$, Zainah Ibrahim ${ }^{3}$ and Sumra Yousuf 4 \\ 1 Centre for Building, Construction \& Tropical Architecture (BuCTA), Faculty of Built Environment, \\ Universiti Malaya, Kuala Lumpur 50603, Malaysia; lohpohyee@gmail.com \\ 2 Department of Civil Engineering, University Tenaga Nasional, Kajang 43000, Malaysia \\ 3 Department of Civil Engineering, Faculty of Engineering, Universiti Malaya, Kuala Lumpur 50603, Malaysia; \\ zainah@um.edu.my \\ 4 Department of Building and Architectural Engineering, Faculty of Engineering \& Technology, \\ Bahauddin Zakariya University, Multan 60000, Pakistan; sumra.yousafrm@gmail.com \\ * Correspondence: pshafigh@gmail.com (P.S.); Herda@uniten.edu.my (H.Y.B.K.)
}

check for updates

Citation: Loh, P.Y.; Shafigh, P.;

Katman, H.Y.B.; Ibrahim, Z.; Yousuf, S. pH Measurement of Cement-Based Materials: The Effect of Particle Size. Appl. Sci. 2021, 11, 8000. https:// doi.org/10.3390/app11178000

Academic Editors: Hugo Filipe Pinheiro Rodrigues and Ivan Duvnjak

Received: 16 June 2021

Accepted: 1 August 2021

Published: 29 August 2021

Publisher's Note: MDPI stays neutral with regard to jurisdictional claims in published maps and institutional affiliations.

Copyright: (c) 2021 by the authors. Licensee MDPI, Basel, Switzerland. This article is an open access article distributed under the terms and conditions of the Creative Commons Attribution (CC BY) license (https:/ / creativecommons.org/licenses/by/ $4.0 /)$.

\begin{abstract}
Healthy reinforced concrete should be highly alkaline to safeguard the passive protective film for reinforcement of steel bars against corrosion. $\mathrm{pH}$ measurement is gaining importance in research of cement-based materials (CBMs), such as paste, mortar and concrete, as well as in structural health monitoring and forensic engineering applications. However, insufficient information is available regarding the most practical, economical and applicable quantitative $\mathrm{pH}$ measurement method for CBMs from the sampling to measurement stage. Existing recommended methods for measuring $\mathrm{pH}$ have many variables that need to be investigated to determine how they influence the $\mathrm{pH}$ value. Samples were recommended to be ground into very fine particles for $\mathrm{pH}$ measurement. Preparing very fine particles of CBMs is costly and time consuming, while larger particles, with sizes similar to sand particles, are easier to obtain, without needing special equipment. This study aims to investigate the effect of different particle sizes on the $\mathrm{pH}$ of cement mortar. Mortar specimens were crushed and sieved to obtain different ranges of particle sizes to measure the $\mathrm{pH}$ values. Results showed that specimens with large particle sizes (between $600 \mu \mathrm{m}$ and $4.75 \mathrm{~mm}$ ) can produce similar results to specimens with very fine particle sizes $(<600 \mu \mathrm{m})$ by increasing the solid-to-solvent ratio or the leaching time.
\end{abstract}

Keywords: pH measurement; $\mathrm{pH}$ value; ex-situ leaching; particle size; cement-based materials

\section{Introduction}

Calcium silicates $\left(\mathrm{C}_{3} \mathrm{~S}\right.$ and $\left.\mathrm{C}_{2} \mathrm{~S}\right)$ are the main cementitious compounds in cement. The hydration and hydrolysis of calcium silicates produces calcium hydroxide $\left(\mathrm{Ca}(\mathrm{OH})_{2}\right.$ or $\mathrm{CH}$ ) [1]. About $25 \%$ of the structural component of cement paste is $\mathrm{CH}$, which increases the $\mathrm{pH}$ of cement-based materials (CBMs) to more than 12 [2]. The high $\mathrm{pH}$ of concrete will enable the formation of a passive protective film on the embedded steel. This thin oxide layer formed on the steel can prevent the metal atoms from dissolving and reduce the corrosion rate to an insignificant level [3]. However, carbonation, $\mathrm{CH}$ leaching, or the presence of ion chloride reduces the amount of $\mathrm{CH}$ and other alkalis in concrete [4]. When the $\mathrm{pH}$ of concrete is reduced to less than 11.5, the passive protective film for the embedded steel will be unstable and the steel will be corroded at the rate of at least 1000 times higher [3-5]. Phenolphthalein solution is typically used as an indicator to test the depth of carbonation from the concrete surface because it changes from pink to colourless when the $\mathrm{pH}$ is less than 9.5 [6]. However, this method is not accurate enough to evaluate the durability of reinforced concrete, where the $\mathrm{pH}$ near the embedded steel is more than $11.5[4,5]$. A more accurate $\mathrm{pH}$ measurement method is needed to evaluate the durability performance of concrete materials, particularly for concrete containing supplementary 
cementitious materials (SCMs). Gruyaert et al. [7] reported that concrete containing SCMs is more vulnerable to carbonation than ordinary Portland cement concrete. Sanjuán et al. [8] also reported that mortars and concretes made of ground granulated blast-furnace slag (GGBFS) cement exhibited higher carbonation rates, particularly when they were poorly cured and had high GGBFS content.

Researchers have investigated the $\mathrm{pH}$ of $\mathrm{CBMs}$ for different purposes. Most studies are related to the passive protective film of embedded steel bars and aim to compare the $\mathrm{pH}$ among different $\mathrm{CBM}$ mixtures [9-11], to monitor the $\mathrm{pH}$ profiles over time [12] and at different depths [6,13-15], to determine the rates of $\mathrm{pH}$ changes [16] and the $\mathrm{pH}$ profiles of CBMs due to early carbonation curing [15,17]. Meanwhile, Kakade [18], and Räsänen and Penttala [19] measured the $\mathrm{pH}$ of a concrete surface for floor covering purposes. Alonso et al. [20] analysed methods for $\mathrm{pH}$ measurement for low-pH CBMs ( $\mathrm{pH}$ about 11) used in a geological repository.

Few studies have used $\mathrm{pH}$ testing and phenolphthalein testing and determined their relation. Zhang and Shao [15] conducted phenolphthalein and $\mathrm{pH}$ measurement tests at different depths of the concrete surface at days 1 and 28 of different concrete mixtures, when the concrete samples were under early carbonation curing. At day 1 , the $\mathrm{pH}$ test results at a carbonation depth of 10-25 mm showed higher variance than those at other depths of $0-10$ and $25-50 \mathrm{~mm}$. However, at day 28 , no carbonation was found on the samples by using the phenolphthalein test, consistent with the $\mathrm{pH}$ test. The author suggested that this finding may be due to the existence of transition zones. McPolin [6] measured the apparent $\mathrm{pH}$ (not true $\mathrm{pH}$ ) value of different carbonated concrete mixtures at different depths of the concrete surface. The measurements were conducted weekly, for a period of 6 weeks. At the 6 th week, a phenolphthalein test was carried out to identify the average carbonation depth. The results showed that, at the average carbonated depth measured by phenolphthalein, the apparent $\mathrm{pH}$ value was within 11.3-11.7.

Behnood et al. [21] stated the lack of standardisation for $\mathrm{pH}$ measurement for concrete and urged the development of a profoundly reproducible and repeatable standard method for fresh and hardened concrete. Researchers typically applied their own consistent measurement methods across different samples for $\mathrm{pH}$ comparison (Figure 1). Pore solution extraction (PSE) method described in Barneyback and Diamond [22] is commonly referred by researches to extract pore solution from the CBMs for further analysis. Sagüés et al. [23] introduced in-situ leaching (ISL) method while ESL is the most widely applied method for $\mathrm{pH}$ measurement for CBMs. Each method has its advantages and disadvantages. However, there are insufficient studies about variables affecting each measurement method.

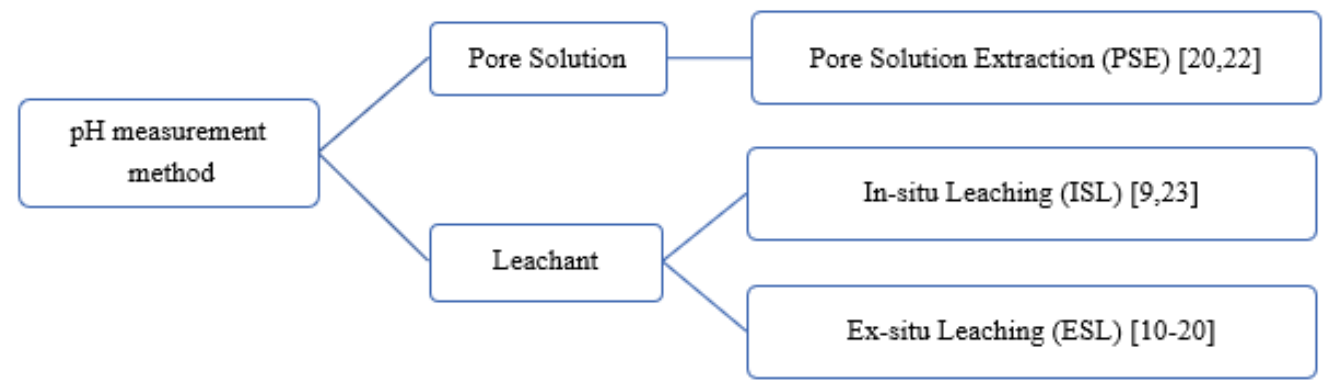

Figure 1. $\mathrm{pH}$ measurement methods categorised by different types of sample preparation.

Among different $\mathrm{pH}$ measurement methods, the ex-situ leaching (ESL) method is economic and simple [24]. ESL has good repeatability and reproducibility [20,25]. Figure 2 illustrates the steps and considerations for each stage of the ESL method; these parameters are inconsistent among researchers, varying from specimen preparation to measurement. Given the lack of a standardised method for ESL, experimental errors may occur due to the wrong selection of variables. As shown in this figure, the first step of measuring $\mathrm{pH}$ 
is to prepare fine particle sizes from the specimens. Table 1 lists the particle sizes used by different researchers $[13,19,25,26]$ in their $\mathrm{pH}$ measurement.

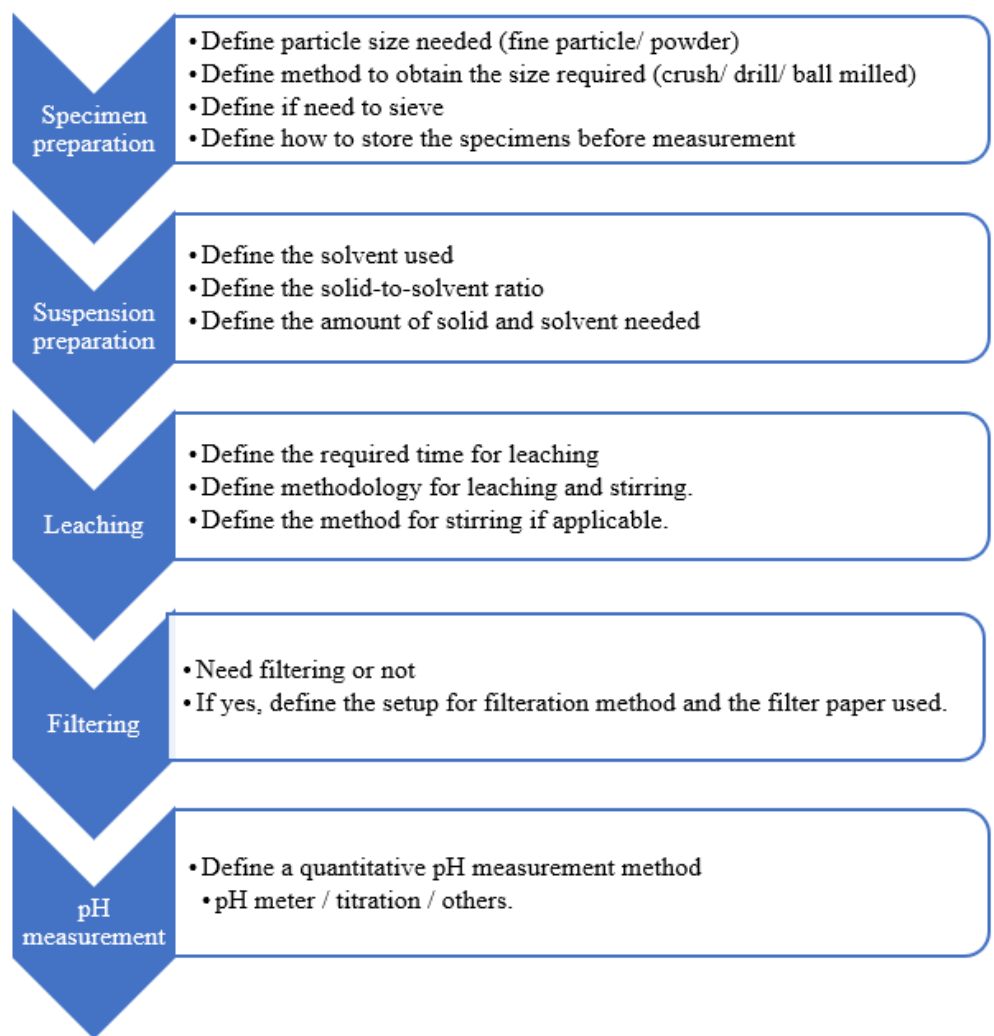

Figure 2. Summary for stages of the ESL method.

Table 1. Particle sizes used by different researchers in the ESL method.

\begin{tabular}{ll}
\hline \multicolumn{1}{c}{ Specimen Particle Size } & \multicolumn{1}{c}{ Reference } \\
\hline Powder from drilling & $\begin{array}{l}\text { McPolin et al. [6], } \\
\text { Heng and Murata [16], } \\
\text { Björk and Eriksson [27] }\end{array}$ \\
\hline$<63 \mu \mathrm{m}$ & Rashad [10] \\
\hline $150 \mu \mathrm{m}$ & Manso and Aguado [24] \\
\hline$<297 \mu \mathrm{m}$ & Li et al. [28] \\
\hline Grind until $<80 \mu \mathrm{m}$, do not use a sieve & Alonso et al. [20] \\
\hline Crush and grind using a vibratory disc mill at & Plusquellec et al. [29] \\
$1500 \mathrm{rpm}$ for $30 \mathrm{~s}$, then sieve to $<80 \mu \mathrm{m}$ & Pavlík [26] \\
\hline$<500 \mu \mathrm{m}, 500 \mu \mathrm{m}-1 \mathrm{~mm}, 1-2 \mathrm{~mm}$ & \\
\hline$<75 \mu \mathrm{m}, 75-125 \mu \mathrm{m}, 125-250 \mu \mathrm{m}$, & Räsänen and Penttala [19] \\
$250-500 \mu \mathrm{m}, 500 \mu \mathrm{m}-1 \mathrm{~mm}, 1-2 \mathrm{~mm}$, & \\
\hline $2-4 \mathrm{~mm}, 4-8 \mathrm{~mm}, 8-16 \mathrm{~mm},>16 \mathrm{~mm}$ & Grubb et al. [13] \\
\hline$<850 \mu \mathrm{m}, 850 \mu \mathrm{m}-2 \mathrm{~mm},>2 \mathrm{~mm}$ & Wang et al. [25] \\
\hline$<74 \mu \mathrm{m}, 74-149 \mu \mathrm{m}, 149-297 \mu \mathrm{m}, 297-595 \mu \mathrm{m}$ & \\
\hline
\end{tabular}

Pavlík [26] measured the concentration of $\mathrm{OH}^{-}$ions (in mmol/L) for cement paste to calculate $\mathrm{pH}$. The equation of $\mathrm{pH}=14+\log [\mathrm{OH}]$ was used in his study. The results showed that smaller particle sizes had a higher $\mathrm{OH}^{-}$concentration, indicating a higher $\mathrm{pH}$ value (more alkaline). Räsänen and Penttala [19] tested concrete from blended cement with 
a solid-to-solvent ratio of 1:1, while Grubb et al. [13] tested concrete samples without fly ash, with a solid-to-solvent ratio of 1:2.

Table 2 shows the $\mathrm{pH}$ values of concrete in two different studies when different particle sizes were used. Specimens with bigger particle sizes had lower $\mathrm{pH}$. Therefore, fine particles should be used for a more accurate measurement of $\mathrm{pH}$ [19]. However, preparing specimens into very fine particles requires more energy and time, compared with using bigger particle sizes.

Table 2. Comparison of the $\mathrm{pH}$ value for biggest and smallest particle sizes in previous studies.

\begin{tabular}{cccc}
\hline \multicolumn{2}{c}{ Grubb et al. [13] } & \multicolumn{2}{c}{ Räsänen and Penttala [19] } \\
\hline Particle Size & pH Measured & Particle Size & pH Measured \\
\hline$>2 \mathrm{~mm}$ & 11.55 & $>16 \mathrm{~mm}$ & 12.22 \\
$<850 \mu \mathrm{m}$ & 12.48 & $<75 \mu \mathrm{m}$ & 12.81 \\
\hline
\end{tabular}

Pavlík [26] reported that the effect of the particle size of Portland cement paste with a high solid-to-solvent ratio of 1:1 is relatively smaller than those with the ratios of 1:2, 1:5 and 1:50.

This study selected the ESL method to standardise a quantitative $\mathrm{pH}$ measurement method for CBMs to cover a wider $\mathrm{pH}$ range than phenolphthalein measurement. This work aims to determine the effects of using different particle sizes on the $\mathrm{pH}$ value of cement mortar and understand the possibility of using large particles (within the range of standard sand particle sizes) instead of using very fine particles for $\mathrm{pH}$ measurement. Similar studies were conducted on concrete and paste materials $[13,19,25,26]$, and the results revealed that large particles had lower $\mathrm{pH}$ than very fine particles. Therefore, very fine particle sizes should be used to measure $\mathrm{pH}$ in the ESL method. No study has investigated the possibility of using large particles in $\mathrm{pH}$ measurement if very fine particles are not available. The use of large particles can benefit researchers and engineers with limited resources for making specimens in powdered form (very fine particle size). In addition, considering that the preparation of samples with large particle sizes is simpler, the time and cost of testing will be reduced.

\section{Research Methodology}

\subsection{Materials}

Low-porosity cement mortar with a cement to sand (c/s) ratio of 1:3 was prepared [30]. For a good workable mortar, a w/c ratio of 0.55 was applied. Ordinary Portland Cement (OPC) Type I (Tasek Corporation Berhad, Ipoh, Malaysia according to MS522 specification), local mining sand with a maximum grain size of $4.75 \mathrm{~mm}$ in saturated-surface-dry (SSD) condition and normal tap water from the pipeline were used. The fresh mortar, with a flow table test result of $220 \mathrm{~mm}$, was cast in $50 \mathrm{~mm}$ cubes, and vibrated in two layers on a vibration table. The specimens were demoulded one day after casting and submerged in normal tap water until the time of testing (the age of specimens was 398 days at the time of testing). The average value of the compressive strength for the mortar sample was $55.7 \mathrm{MPa}$.

\section{2. $p H$ Meter Selection and Other Instruments}

The main components of $\mathrm{pH}$ meter are an electrochemical system (a pH sensor and a reference electrode), a high input impedance meter (which processes the voltage difference in $\mathrm{DC}$ millivolt and displays them in $\mathrm{mV}$ or $\mathrm{pH}$ ) and a temperature sensor. The reference electrode provides stable and constant reference voltage but is completely insensitive to the measured fluid. The junction of the reference electrode may be contaminated under adverse condition, such as high temperature, high pressure, high acidity and high basicity. An under-performing reference electrode can cause the $\mathrm{pH}$ reading to drift. Therefore, the reference electrode should be used carefully, according to the supplier's recommendation, 
and/or a double-junction electrode should be selected, instead of a single-junction electrode, to minimise contamination

The quality of electrodes degrades overtime depending on usage and maintenance, as evident in response time, slope and offset of the $\mathrm{pH}$ electrode. Response time refers to the time taken to obtain a stable reading. In theory, a perfect $\mathrm{pH}$ electrode reads $0 \mathrm{mV}$ at $\mathrm{pH} 7$ buffer at $25{ }^{\circ} \mathrm{C}$, with a slope of $59.16 \mathrm{mV} / \mathrm{pH}$. For a clean, correctly calibrated, and in good condition electrode, at $25^{\circ} \mathrm{C}$, the slope shall be within $92 \%$ to $110 \%$, where $100 \%$ is $59.16 \mathrm{mV} / \mathrm{pH}$, while the offset shall be $\pm 30 \mathrm{mV}$ [31]. Before the test, calibration was performed with at least one to five standard buffer solutions, depending on the capability of the $\mathrm{pH}$ meter.

The suspension of CBMs consists of hard and sharp particles. The $\mathrm{pH}$ measurement was carried out in filtered aqueous solutions to protect the $\mathrm{pH}$-sensitive glass sensor from physical damage. The Hanna Instrument [32] recommends the use of plastic beakers to minimise any EMC interferences during the measurement.

This experiment used the Hanna edge ${ }^{\circledR}$ pH HI2002 and Hanna digital pH electrode HI11310, with a resolution of $0.01 \mathrm{pH}$ and accuracy of $\pm 0.01 \mathrm{pH}$. The instrument has an automatic temperature compensation feature between $-5{ }^{\circ} \mathrm{C}$ and $100{ }^{\circ} \mathrm{C}$ because of its built-in temperature sensor. This double-junction electrode has a $9.5 \mathrm{~mm}$ spherical tip.

\subsection{Experimental Procedure}

Test cubes were left to surface dry for about $15 \mathrm{~min}$ and crushed into pieces that could pass through sieve mesh no. $4(4.75 \mathrm{~mm})$. Throughout the test, $\mathrm{CO}_{2}$ contamination on the specimens was minimised by keeping a distance from the operator's exhalation or other sources [23]. Wang et al. [25] reported insignificant $\mathrm{pH}$ difference (standard deviation of \pm 0.03 ) among paste powder samples exposed to air for $0,1,5,10,20,30,60$ and $120 \mathrm{~min}$ before mixing with deionised water. The specimens and liquid used were maintained at room temperature throughout the test. The specimens for $\mathrm{pH}$ measurement were sieved to obtain at least $50 \mathrm{~g}$ for each category as shown below:

(1) Mesh no. 8-to obtain particle size between 2.36 and $4.75 \mathrm{~mm}$ diameter;

(2) Mesh no. 16-to obtain particle size between 1.18 and $2.36 \mathrm{~mm}$ diameter;

(3) Mesh no. 30-to obtain particle size between $600 \mu \mathrm{m}$ and $1.18 \mathrm{~mm}$ diameter;

(4) Mesh no. 50 - to obtain particle size between 300 and $600 \mu \mathrm{m}$ diameter;

(5) Mesh no. 100-to obtain particle size between 150 and $300 \mu \mathrm{m}$ diameter;

(6) Base tray - to obtain particle size between less than $150 \mu \mathrm{m}$ diameter.

Grubb et al. [13] and Plusquellec et al. [29] milled the specimens to measure the pH of CBMs. For comparison, about $100 \mathrm{~g}$ of crushed specimens were ground using planetary ball mills. The majority of these specimens passed through the $150 \mu \mathrm{m}$ sieve after the milling process. Figure 3 displays the specimens with different sizes for the test. Fine powder appeared lighter in colour than large particles.

Each category of the specimens was stored in individual, sealed plastic bags. Before the test, the $\mathrm{pH}$ meter was calibrated with standard buffer solutions of 4.01, 7.01 and 10.01, with an offset of $\pm 30 \mathrm{mV}$ and slope ranging between $92 \%$ and $110 \%$. 


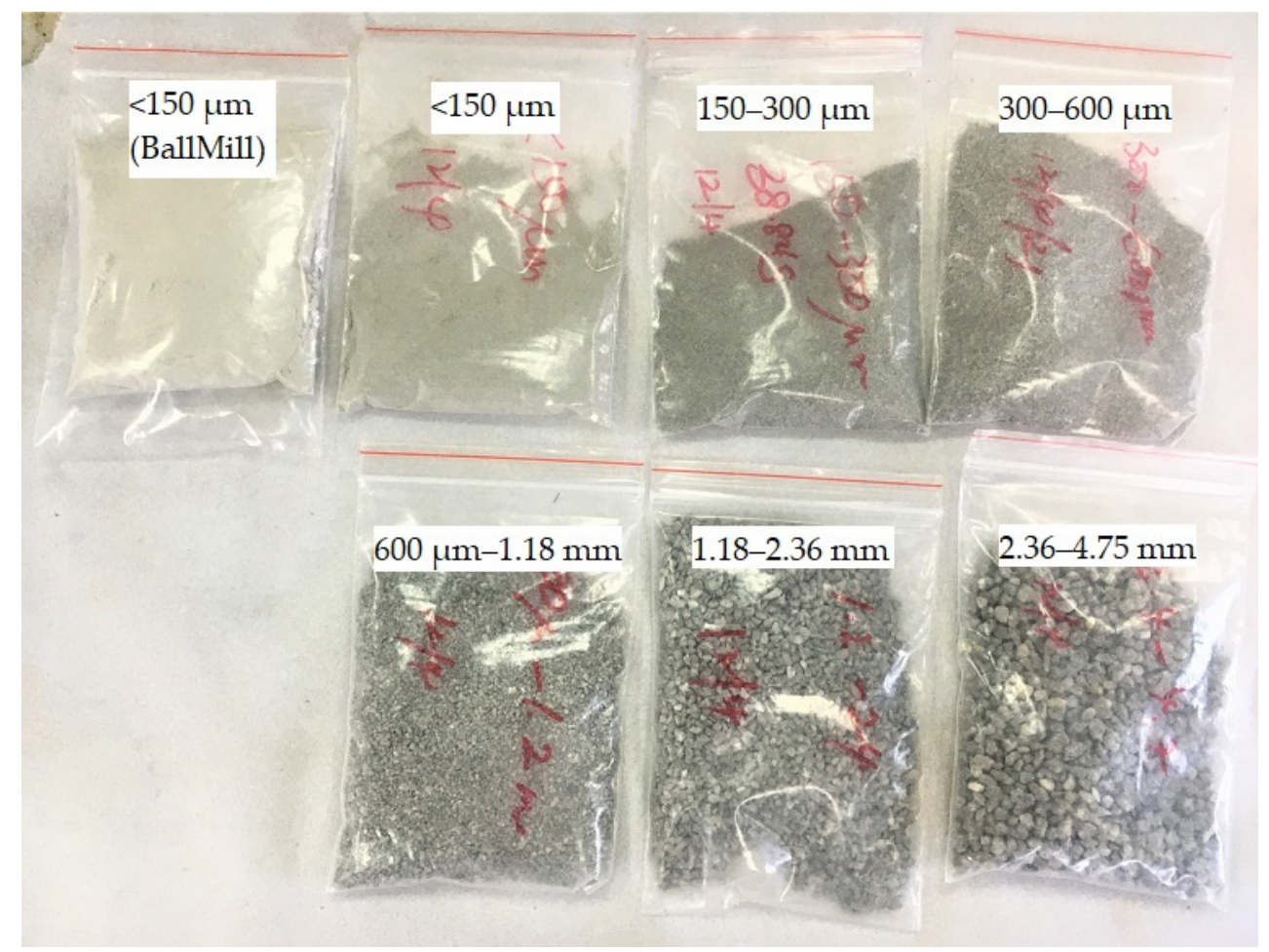

Figure 3. Samples stored in individual, sealed plastic bags.

In a $50 \mathrm{~mL}$ self-standing centrifuge tube, $10 \pm 0.1 \mathrm{~g}$ of the specimens was added to $20 \pm 0.1 \mathrm{~g}$ of fresh distilled water, followed by magnetic stir bar, before tightening the screw cap on the tube. The tube was placed on the magnetic stirrer to stir without heating for $5 \mathrm{~min}$ of leaching. The suspension was filtered through a quantitative ashless filter paper Grade 40 by using a Buchner funnel filter to obtain at least $10 \mathrm{~mL}$ of the solution. The filtered solution was immediately poured into a clean $50 \mathrm{~mL}$ self-standing centrifuge tube for $\mathrm{pH}$ measurement. The solution level was higher than the ceramic junction and stirred during the measurement. The meter was set to log the reading in stability-accurate mode to avoid human error. For each sample, three readings were recorded, and the mean value was taken. The test was conducted randomly until three samples were tested for each particle size. The estimated time for the experiment (after the specimens were separated into respective sizes) was as follows: preparation of the suspension: within $5 \mathrm{~min}$; stirring and leaching: $5 \mathrm{~min}$; filtering: within $1 \mathrm{~min}$ and $\mathrm{pH}$ measurement: within $5 \mathrm{~min}$.

Figure 4 summarises the variables set for the benchmark methodology to test the effect of different particle sizes. Alonso et al. [20] and Wang et al. [25] applied 5 min of mixing with magnetic stirrer for leaching $10 \mathrm{~g}$ of powder, with the solid-to-solvent ratio of 1:1. The solid-to-solvent ratio of 1:2 for the benchmark methodology was set instead of 1:1, given that Grubb et al. [13] commented that this ratio was practical for the measurement. In brief, $20 \mathrm{~g}$ of water was chosen so that the filtered solution in the $50 \mathrm{~mL}$ tube was higher than the ceramic junction of the electrode during $\mathrm{pH}$ measurement. The suspension was filtered with Grade 40 filter paper to protect the electrode from physical damages [13,29]. A Bushner funnel was also used to prevent carbonisation during filtering. 


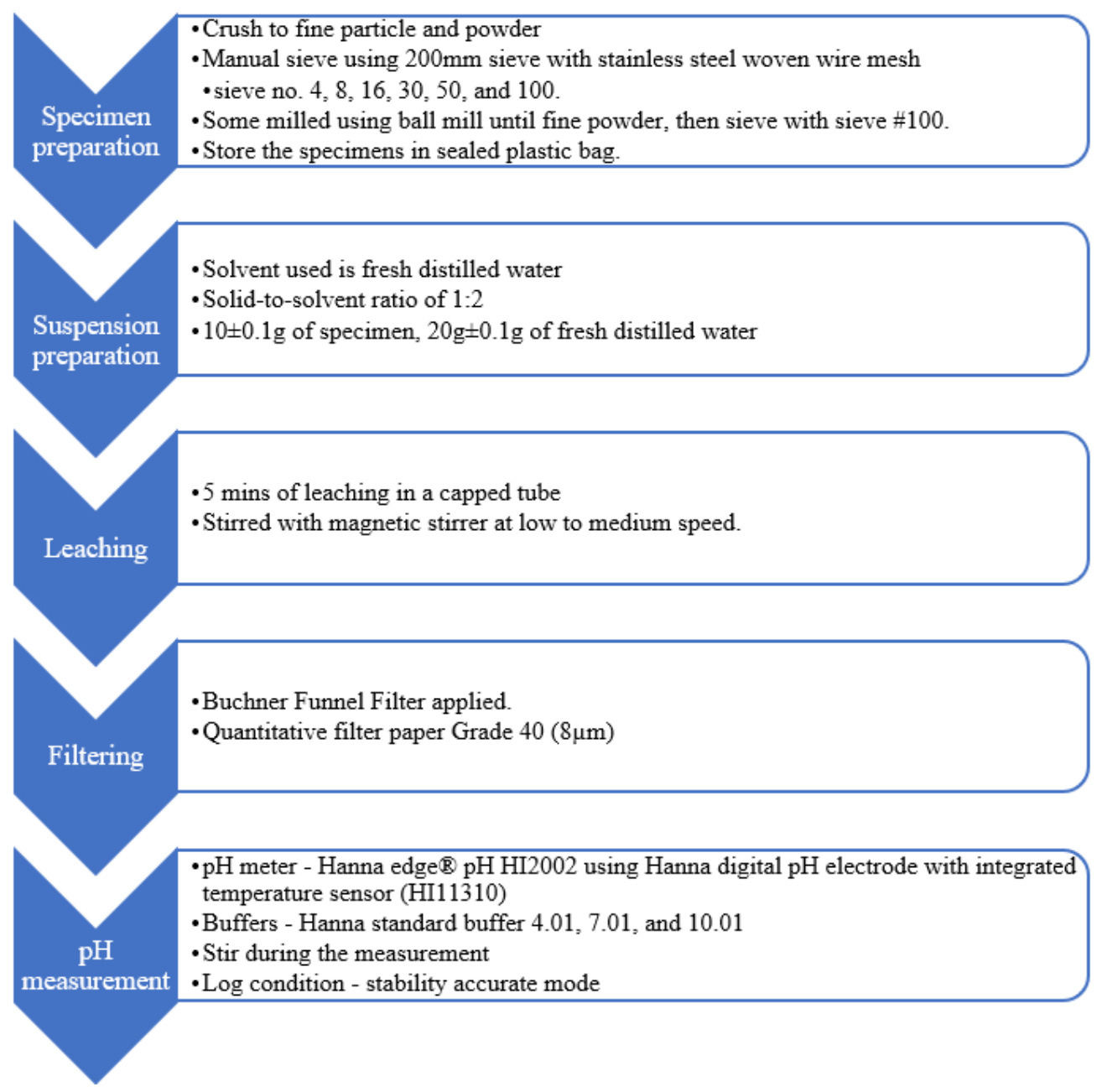

Figure 4. Benchmark methodology for effect of particle size.

\section{Results and Discussion}

\subsection{Effect of Particle Size on $\mathrm{pH}$}

When a solid particle breaks into smaller particles, the total surface area increases. A large surface area allows more chemical reactions than a small surface area. Therefore, CBMs with smaller particle sizes have a higher total surface area in contact with solvent for the leaching of the $\mathrm{OH}^{-}$ion [33]. Figure 5 shows that larger particle sizes have a lower $\mathrm{pH}$ value, as evident in particle sizes of $2.36-4.75 \mathrm{~mm}$ to $0.60-1.18 \mathrm{~mm}$. For particle sizes of $2.36-4.75 \mathrm{~mm}$, the $\mathrm{pH}$ is about 0.26 units lower than very fine particles $(<150 \mu \mathrm{m}$ using ball mill). Fine particles with sizes below $600 \mu \mathrm{m}$ have a pH differential of less than 0.05 units. For $\mathrm{pH}$ measurement, the sample particle sizes could be divided into two zones, namely, large particle size (particle sizes larger than $600 \mu \mathrm{m}$ ) and fine particle size (particle sizes smaller than $600 \mu \mathrm{m}$ ). Figure 5 also shows that the proposed $\mathrm{pH}$ measurement method has good repeatability, as the standard deviations are 0.05 or less for each category of particle size, as can be seen in Table 3. The standard deviation for each particle size denotes that the electrode probe has high accuracy during the measurement. 


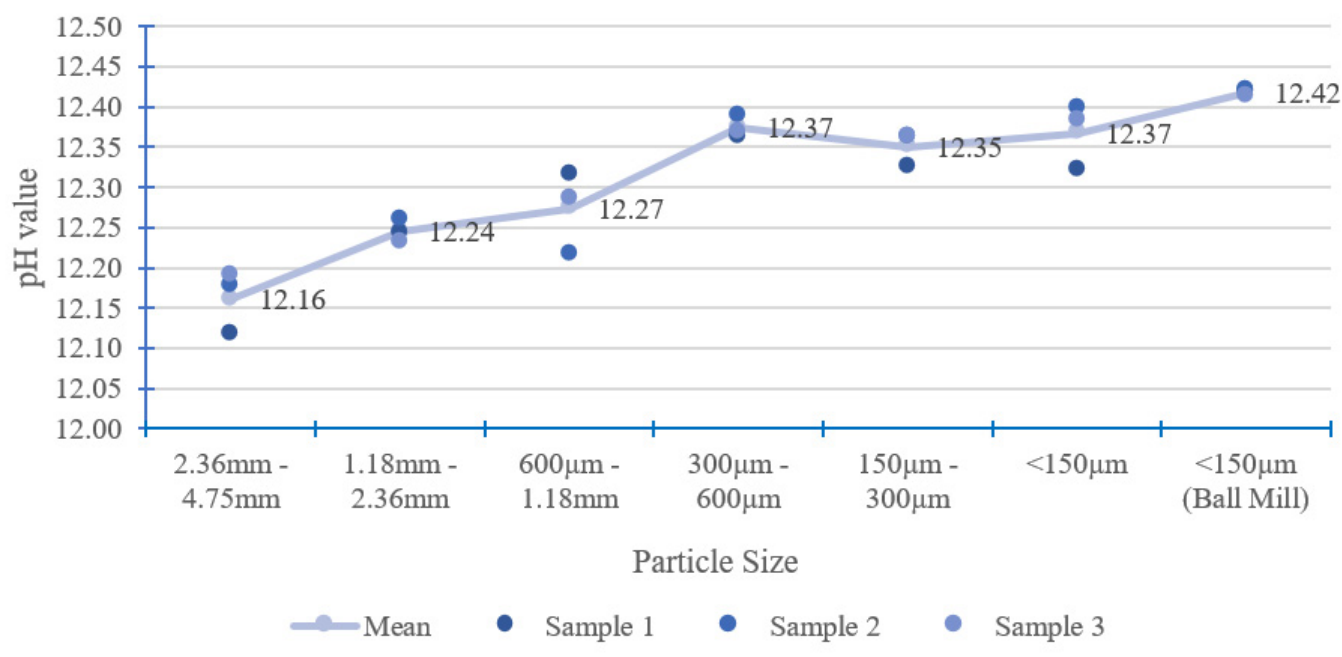

Figure 5. Effect of particle size.

Table 3. Comparison for $\mathrm{pH}$ among mortar, paste and concrete samples with similar particle sizes.

\begin{tabular}{cccc}
\hline & \multicolumn{3}{c}{ pH Value } \\
\cline { 2 - 4 } Particle Size & $\begin{array}{c}\text { In This Study } \\
\text { (Mortar) }\end{array}$ & $\begin{array}{c}\text { Wang et al. [25] } \\
\text { (Paste) }\end{array}$ & $\begin{array}{c}\text { Räsänen and Penttala [19] } \\
\text { (Concrete) }\end{array}$ \\
\hline $2.36-4.75 \mathrm{~mm}$ & $12.16 \pm 0.04$ & N.A. & 12.53 \\
$1.18-2.36 \mathrm{~mm}$ & $12.24 \pm 0.02$ & N.A. & 12.64 \\
$600 \mu \mathrm{m}-1.18 \mathrm{~mm}$ & $12.27 \pm 0.05$ & N.A. & 12.72 \\
$300-600 \mu \mathrm{m}$ & $12.37 \pm 0.02$ & 12.73 & 12.74 \\
$150-300 \mu \mathrm{m}$ & $12.35 \pm 0.02$ & 12.73 & 12.77 \\
$<150 \mu \mathrm{m}$ & $12.37 \pm 0.04$ & 12.77 & 12.79 \\
\hline
\end{tabular}

The results for cement mortar are consistent with the findings from other research (for similar particle size) but differ for CBMs, such as cement paste and concrete (Table 3). The $\mathrm{pH}$ value in the reference paper is higher than that in the present study, possibly due to the different calibration buffers used; this discrepancy requires further study for clarification. Wang et al. [25] determined the $\mathrm{pH}$ of cement paste by using calibration buffer solutions of 4, 7 and 10. Räsänen and Penttala [19] studied the $\mathrm{pH}$ of concrete by using calibration buffers of 10,11, 12 and 13. The table also shows the similar trends of $\mathrm{pH}$ values for large and fine particle sizes.

\subsection{Possibility of Using Samples with Large Particle Sizes in Measuring $p H$}

Grubb et al. [13] reported that particle size influences the $\mathrm{pH}$ of CBMs, such that large particles showed lower $\mathrm{pH}$ than fine particles. Räsänen and Penttala [19] recommended that the particle size of samples should be fine or very fine to obtain an accurate result for the $\mathrm{pH}$ of cement-based materials; however, preparing fine particles is more difficult than large particles. Given the idea of using large particles for $\mathrm{pH}$ measurement, the following variables were examined.

\subsubsection{Effect of Solid-to-Solvent Ratio on $\mathrm{pH}$}

The effect of solid-to-solvent ratio for large particles was determined. Large particle sizes refer to particles larger than $600 \mu \mathrm{m}$, while fine particle sizes refer to particles smaller than $600 \mu \mathrm{m}$. The solid-to-solvent ratio was changed from 1:2 to 1:1, where $20 \mathrm{~g}$ of solid was mixed with $20 \mathrm{~g}$ of fresh distilled water. On the same day, and with the same batch of specimens, samples with a size of 300-600 $\mu \mathrm{m}$ were tested according to the benchmark methodology for reference (Figure 2). The measured $\mathrm{pH}$ of $12.35 \pm 0.02$ matched the results reported in Section 3.1. 
Table 4 shows the $\mathrm{pH}$ test results of three different ranges of large particle sizes (large particle sizes in ranges I, II and III) with the solid-to-solvent ratio of 1:1 in comparison with the $\mathrm{pH}$ value of fine particle sizes with the solid-to-solvent ratio of 1:2. With increasing solid-to-solvent ratio of the large particle sizes, the $\mathrm{pH}$ value of the range III particle size is similar to the reference, whereas that of the range II particle size differs from the reference. A meaningful difference was found between the range I particle size and the reference. By increasing the quantity of solid in the same amount of solvent, the total surface area increases, and a higher $\mathrm{pH}$ value (equal or close) than the reference could be achieved.

Table 4. Effect of the solid-to-solvent ratio of different large particle sizes on $\mathrm{pH}$.

\begin{tabular}{|c|c|c|c|c|}
\hline \multirow[b]{2}{*}{ Particle Size } & \multicolumn{3}{|c|}{ Large Particle Size } & \multirow{2}{*}{$\begin{array}{c}\text { Fine Particle Size } \\
\begin{array}{c}300-600 \mu \mathrm{m} \\
\text { (Reference) }\end{array}\end{array}$} \\
\hline & $\begin{array}{c}2.36-4.75 \mathrm{~mm} \\
\text { (Particle Size Range I) }\end{array}$ & $\begin{array}{c}1.18-2.36 \mathrm{~mm} \\
\text { (Particle Size Range II) }\end{array}$ & $\begin{array}{c}\quad 600 \mu \mathrm{m}-1.18 \mathrm{~mm} \\
\text { (Particle Size Range III) }\end{array}$ & \\
\hline solid-to-solvent ratio & $1: 1$ & $1: 1$ & $1: 1$ & $1: 2$ \\
\hline $\mathrm{pH}$ value (mean $\pm \mathrm{SD}$ ) & $12.23 \pm 0.02$ & $12.31 \pm 0.04$ & $12.35 \pm 0.02$ & $12.35 \pm 0.02$ \\
\hline
\end{tabular}

Figure 6 shows the $\mathrm{pH}$ values of the three ranges of large particle size with different solid-to-solvent ratios. The $\mathrm{pH}$ increased by about 0.07 units when the quantity of the solid samples was doubled for all the three ranges of the large particle size. Grubb et al. [13] reported that when the solid-to-solvent ratio of ground cement paste was changed from 1:2 to 1:1 (with $20 \mathrm{~g}$ of water), the $\mathrm{pH}$ increased by about 0.05 units. Räsänen and Penttala [19] tested the solid-to-solvent ratio for 7-day-old normal-strength concrete (NSC-7) and 180day-old high-strength concrete (HSC-180), which were ground into powder. When the solidto-solvent ratio was increased from 1:2 to $1: 1$, the $\mathrm{pH}$ value increased by approximately 0.04 units for NSC-7 and 0.12 units for HSC-180. The change in the solid-to-solvent ratio from 1:2 to 1:1 did not contribute much to the $\mathrm{pH}$ increment compared with the large particle sizes tested.

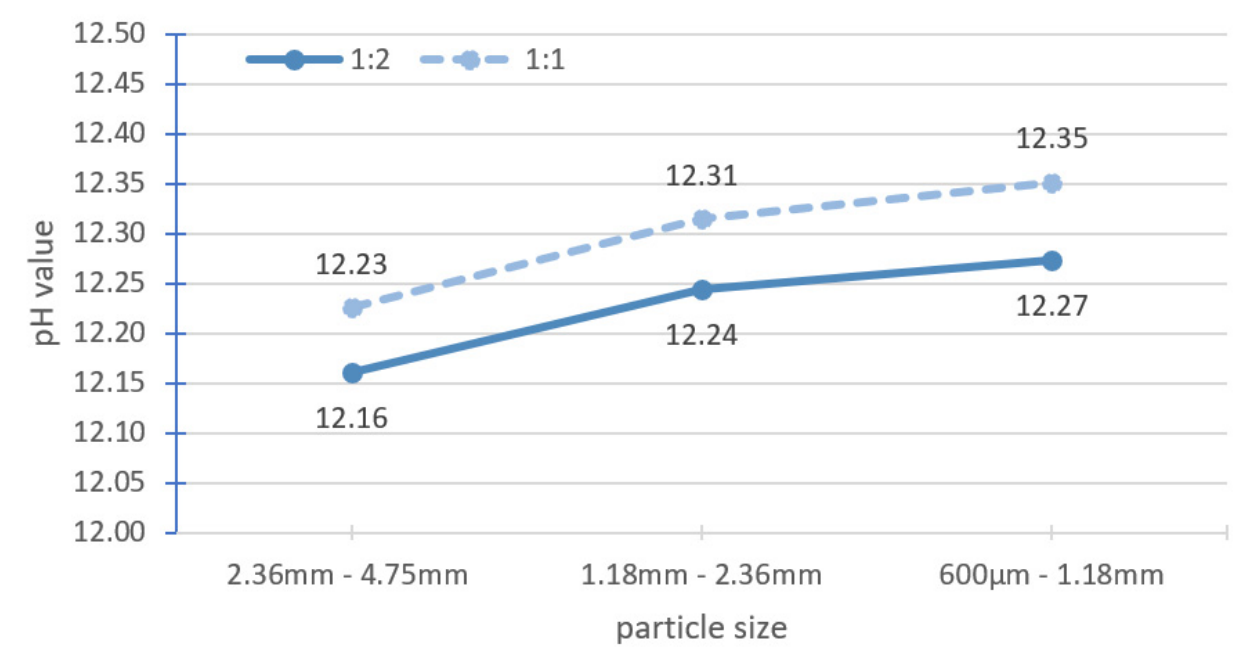

Figure 6. Effect of solid-to-solvent ratio of 1:1 and 1:2 for large particle size.

\subsubsection{Effect of Leaching Time on $\mathrm{pH}$}

The leaching time was increased to investigate the possibility of using large particle sizes for accurate $\mathrm{pH}$ measurement. The specimens were placed in a magnetic stirrer for $10 \mathrm{~min}$ of leaching instead of $5 \mathrm{~min}$. The reference sample was treated similarly to the method in Section 3.2.1, and the solid-to-solvent ratio for all specimens was 1:2. The test results are shown in Table 5. With increasing leaching time, the $\mathrm{pH}$ also increases, indicating that the leaching time for the benchmark methodology (Figure 4) may not be sufficient when the particle size of the specimens was large. The $\mathrm{pH}$ values of the ranges I 
and II large particle sizes are almost the same as the reference sample, but higher than that of the range III large particle size.

Table 5. Effect of leaching time for different large particle sizes on $\mathrm{pH}$.

\begin{tabular}{|c|c|c|c|c|}
\hline \multirow[b]{2}{*}{ Particle Size } & \multicolumn{3}{|c|}{ Large Particle Size } & \multirow{2}{*}{$\begin{array}{c}\text { Fine Particle Size } \\
\begin{array}{c}300-600 \mu \mathrm{m} \\
\text { (Reference) }\end{array}\end{array}$} \\
\hline & $\begin{array}{c}2.36-4.75 \mathrm{~mm} \\
\text { (Particle Size Range I) }\end{array}$ & $\begin{array}{c}1.18-2.36 \mathrm{~mm} \\
\text { (Particle Size Range II) }\end{array}$ & $\begin{array}{c}600 \mu \mathrm{m}-1.18 \mathrm{~mm} \\
\text { (Particle Size Range III) }\end{array}$ & \\
\hline Leaching time (min) & 10 & 10 & 10 & 5 \\
\hline $\mathrm{pH}$ value (mean $\pm \mathrm{SD}$ ) & $12.32 \pm 0.03$ & $12.38 \pm 0.02$ & $12.43 \pm 0.03$ & $12.35 \pm 0.02$ \\
\hline
\end{tabular}

Figure 7 shows an average increment in the $\mathrm{pH}$ value of about 0.15 for large particle sizes when the leaching time is increased from $5 \mathrm{~min}$ to $10 \mathrm{~min}$. Räsänen and Penttala [19] utilised a CM200 cell mixer with the speed of $35 \mathrm{rpm}$ to stir the suspension. The stirring speed is slower than that of magnetic stirring used in the present study. For NSC-180, when the stirring time is increased from $5 \mathrm{~min}$ to $15 \mathrm{~min}$, the $\mathrm{pH}$ increases by 0.01 units. Grubb et al. [13] recorded an insignificant $\mathrm{pH}$ change of approximately 0.05 units for a leaching time of 30-60 min. In both studies, the $\mathrm{pH}$ tests were conducted on the fine particle size (powder form).

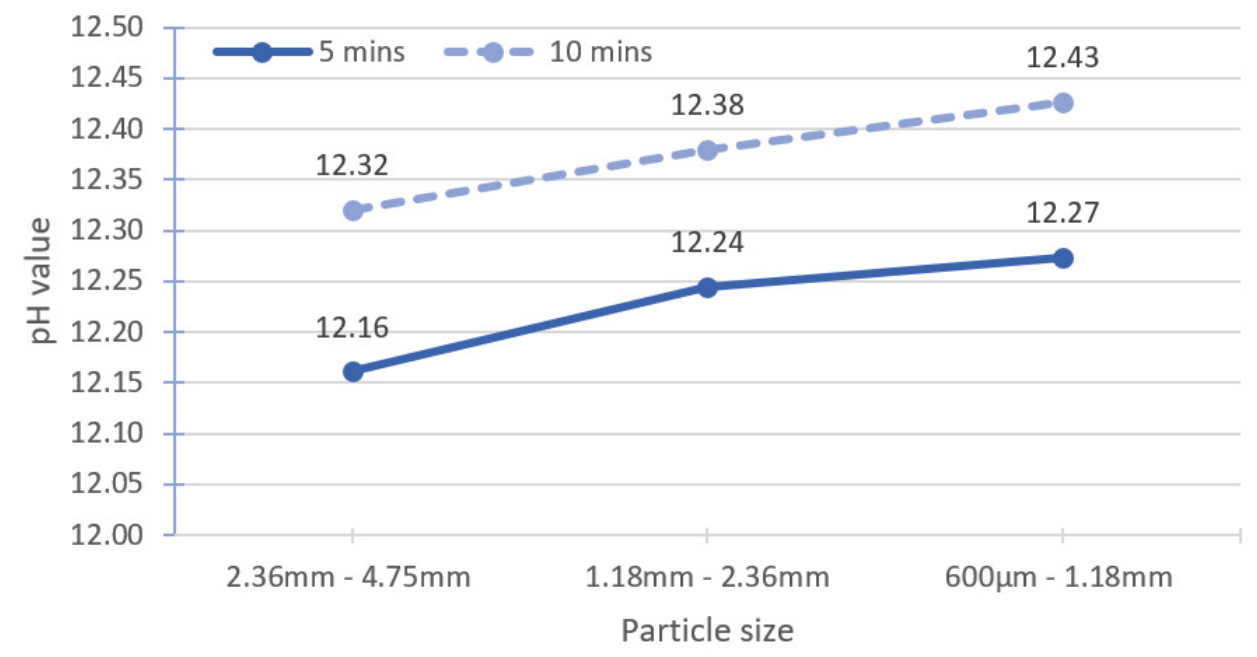

Figure 7. Effect of changing leaching time to $10 \mathrm{~min}$ for large particle size.

\section{Conclusions}

As a part of durability and serviceability assessment of a concrete structure, the $\mathrm{pH}$ of structural concrete is one of the fundamental indicators to ensure that the concrete structure is in healthy condition or assess whether it needs rehabilitation and maintenance. Considering the lack of a standard for $\mathrm{pH}$ measurement, especially for high $\mathrm{pH}$ ranges, this work investigated the possibility of using large particle sizes, instead of fine particle sizes, for CBMs (cement mortar) to simplify the method of $\mathrm{pH}$ measurement.

Cement mortar specimens with smaller particle sizes resulted in a higher $\mathrm{pH}$ value, consistent with the studies on cement paste and concrete. Using a particle size of less than $600 \mu \mathrm{m}$ (fine particle size) showed consistent $\mathrm{pH}$ measurement with a mean of 12.37-12.42 for cement mortar. In addition, large particle sizes (particle sizes between $2.36 \mathrm{~mm}$ and $600 \mu \mathrm{m}$ ) can be used for accurate $\mathrm{pH}$ measurement if the solid-to-solvent ratio is increased from 1:2 (used for fine particle sizes) to 1:1 or the leaching time is doubled (from $5 \mathrm{~min}$ for fine particle sizes to $10 \mathrm{~min}$ ). However, increasing the leaching time is recommended, rather than increasing the solid-to-solvent ratio to obtain similar $\mathrm{pH}$ readings as fine particle size.

These findings are important for the development of a standardised $\mathrm{pH}$ measurement using the ESL method for CBMs. The effect of other variables should be investigated on 
different types of CBMs to verify the applicability of all variables before a standardised $\mathrm{pH}$ measurement can be proposed.

Author Contributions: Conceptualization, P.Y.L. and P.S.; methodology, P.Y.L. and P.S.; software, P.Y.L.; validation, P.Y.L., P.S., H.Y.B.K., Z.I. and S.Y.; formal analysis, P.Y.L. and P.S.; investigation, P.Y.L.; resources, P.Y.L.; data curation, P.Y.L. and P.S.; writing—original draft preparation, P.Y.L.; writing—review and editing, P.Y.L., P.S., H.Y.B.K., Z.I. and S.Y.; visualization, P.Y.L.; supervision, P.S. and Z.I.; funding acquisition, P.S. and H.Y.B.K. All authors have read and agreed to the published version of the manuscript.

Funding: This research is supported by Universiti Tenaga Nasional Internal Research Grant OPEX (J5100D4103-BOLDREFRESH2025-CENTRE OF EXCELLENCE) and Universiti Malaya research grant (Grant No. GPF007F-2019).

Institutional Review Board Statement: Not applicable.

Informed Consent Statement: Not applicable.

Data Availability Statement: The data presented in this study are available within the article.

Acknowledgments: The authors would like to express their gratitude for the provided support by Universiti Malaya and Universiti Tenaga Nasional.

Conflicts of Interest: The authors declare no conflict of interest.

\section{References}

1. Neville, A.M. Portland cement. In Properties of Concrete, 5th ed.; Pearson Education Limited: London, UK, 2011.

2. Li, Z.J. Materials for making concrete. In Advanced Concrete Technology; John Wiley \& Sons. Inc.: Hoboken, NJ, USA, 2011; p. 38.

3. ACI Committee 222. Protection of Metals in Concrete Against Corrosion; American Concrete Institute: Farmington Hills, MI, USA, 2001.

4. Taylor, H.F.W. Concrete chemistry. In Cement Chemistry; Academic Press Limited: London, UK, 1990; pp. 383-387.

5. Kurdowski, W. Concrete Properties. In Cement and Concrete Chemistry; Springer: Dordrecht, The Netherlands, 2014; p. 478. [CrossRef]

6. McPolin, D.O.; Bashneer, P.A.M.; Long, A.E.; Grattan, K.T.V.; Sun, T. New test method to obtain pH profiles due to carbonation of concretes containing supplementary cementitious materials. J. Mater. Civ. Eng. 2007, 19, 936-956. [CrossRef]

7. Gruyaert, E.; Van Den Heede, P.; De Belie, N. Carbonation of slag concrete: Effect of the cement replacement level and curing on the carbonation coefficient-Effect of carbonation on the pore structure. Cem. Concr. Comp. 2013, 35, 39-48. [CrossRef]

8. Sanjuán, M.A.; Estévez, E.; Argiz, C.; Del Barrio, D. Effect of curing time on granulated blast-furnace slag cement mortars carbonation. Cem. Concr. Comp. 2018, 90, 257-265. [CrossRef]

9. Li, L.F.; Sagüés, A.A.; Poor, N. In situ leaching investigation of $\mathrm{pH}$ and nitrite concentration in concrete pore solution. Cem. Concr. Res. 1999, 29, 315-321. [CrossRef]

10. Rashad, A.M. An investigation on very high volume slag pastes subjected to elevated temperatures. Constr. Build. Mater. 2015, 74, 249-258. [CrossRef]

11. Shafigh, P.; Yousuf, S.; Lee, C.J.; Ibrahim, Z. The effect of cement mortar composition on the pH value. IOP Conf. Ser. Mater. Sci. Eng. 2020, 770, 012026. [CrossRef]

12. Gowripalan, N.; Mohamed, H.M. Chloride-ion induced corrosion of galvanized and ordinary steel reinforcement in highperformance concrete. Cem. Concr. Res. 1998, 28, 1119-1131. [CrossRef]

13. Grubb, J.A.; Limaye, H.S.; Ashok, M.K. Testing pH of Concrete. Concr. Int. 2007, 29, 78-83.

14. Rostami, V.; Shao, Y.X.; Boyd, A.J. Durability of concrete pipes subjected to combined steam and carbonation curing. Constr. Build. Mater. 2011, 25, 3345-3355. [CrossRef]

15. Zhang, D.; Shao, Y.X. Effect of early carbonation curing on chloride penetration and weathering carbonation in concrete. Constr. Build. Mater. 2016, 123, 516-526. [CrossRef]

16. Heng, M.; Murata, K. Aging of concrete buildings and determining the $\mathrm{pH}$ value on the surface of concrete by using a handy semi-conductive $\mathrm{pH}$ meter. Anal. Sci. 2004, 20, 1087-1090. [CrossRef] [PubMed]

17. Rostami, V.; Shao, Y.X.; Boyd, A.J.; He, Z. Microstructure of cement paste subject to early carbonation curing. Cem. Concr. Res. 2012, 42, 186-193. [CrossRef]

18. Kakade, A.M. Measuring concrete surface $\mathrm{pH}-\mathrm{A}$ proposed test method. Concr. Repair Bull. 2014, 16-20. Available online: https://cdn.ymaws.com/www.icri.org/resource/resmgr/crb/2014marapr/CRBMarApr14_Kakade.pdf (accessed on 16 June 2021).

19. Räsänen, V.; Penttala, V. The pH measurement of concrete and smoothing mortar using a concrete powder suspension. Cem. Concr. Res. 2004, 34, 813-820. [CrossRef] 
20. Alonso, M.C.; Calvo, J.L.G.; Walker, C.; Naito, M.; Pettersson, S.; Puigdomenech, I.; Cuñado, M.A.; Vuorio, M.; Weber, H.; Ueda, H.; et al. Development of an Accurate pH Measurement Methodology for the Pore Fluids of Low pH Cementitious Materials; SKB R-12-02; Swedish Nuclear Fuel and Waste Management Co.: Stockholm, Sweden, 2012.

21. Behnood, A.; Van Tittelboom, K.; De Belie, N. Methods for measuring pH in concrete: A review. Constr. Build. Mater. 2016, 105, 176-188. [CrossRef]

22. Barneyback Jr, R.; Diamond, S. Expression and analysis of pore fluids from hardened cement pastes and mortars. Cem. Concr. Res. 1981, 11, 279-285. [CrossRef]

23. Sagüés, A.A.; Moreno, E.I.; Andrade, C. Evolution of pH during in-situ leaching in small concrete cavities. Cem. Concr. Res. 1997, 27, 1747-1759. [CrossRef]

24. Manso, S.; Aguado, A. A review of sample preparation and its influence on $\mathrm{pH}$ determination in concrete samples. Mater. Construcción 2017, 67, 1-10. [CrossRef]

25. Wang, W.C.; Huang, W.H.; Lee, M.Y.; Duong, H.T.H.; Chang, Y.H. Standardized Procedure of Measuring the pH Value of Cement Matrix Material by Ex-Situ Leaching Method (ESL). Crystals 2021, 11, 436. [CrossRef]

26. Pavlík, V. Water extraction of chloride, hydroxide and other ions from hardened cement pastes. Cem. Concr. Res. 2000, 30, 895-906. [CrossRef]

27. Björk, F.; Eriksson, C.A. Measurement of alkalinity in concrete by a simple procedure, to investigate transport of alkaline material from the concrete slab to a self-levelling screed. Constr. Build. Mater. 2002, 16, 535-542. [CrossRef]

28. Li, L.F.; Nam, J.; Hartt, W.H. Ex situ leaching measurement of concrete alkalinity. Cem. Concr. Res. 2005, 35, 277-283. [CrossRef]

29. Plusquellec, G.; Geiker, M.; Lindgård, J.; Duchesne, J.; Fournier, B.; De Weerdt, K. Determination of the pH and the free alkali metal content in the pore solution of concrete: Review and experimental comparison. Cem. Concr. Res. 2017, 96, 13-26. [CrossRef]

30. Shafigh, P.; Asadi, P.; Akhiani, A.R.; Mahyuddin, N.B.; Hashemi, M. Thermal properties of cement mortar with different mix proportions. Mat. Constr. 2020, 70, 224. [CrossRef]

31. Hanna Instruments. pH. In General Catalog; Hanna Instruments Inc.: Woonsocket, RI, USA, 2020; Volume 34, pp. 2.1-2.170.

32. Hanna Instruments. Operational guide. In edge®pH Instruction Manual; Hanna Instruments Inc.: Woonsocket, RI, USA; p. 37. Available online: https:/ / www.manualslib.com/manual/1555430/Hanna-Instruments-Edge.html\#manual (accessed on 15 June 2021).

33. Meyers, R.A. Encyclopedia of Environmental Analysis and Remediation. 8 Volume Set; Wiley-Interscience: New York, NY, USA, 1998; p. 2094. 